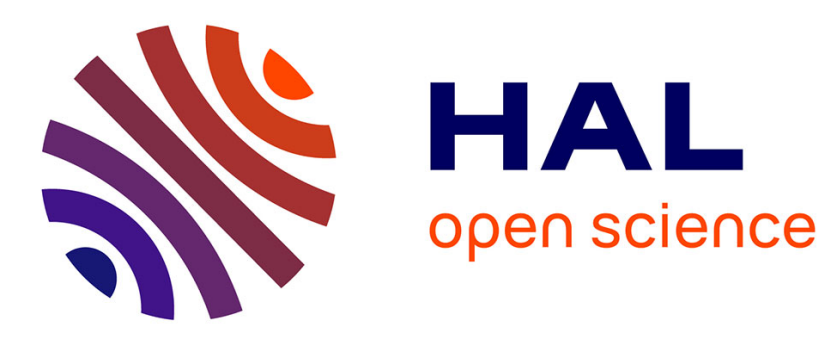

\title{
Sufism and Shi'ism in South Asia: shahadat and the Evidence of the Sindhi marthiya
}

Michel Boivin

\section{To cite this version:}

Michel Boivin. Sufism and Shi'ism in South Asia: shahadat and the Evidence of the Sindhi marthiya. Shi'i Islam and Sufism.Classical Views and Modern Perspectives, 2020. hal-03090157

\section{HAL Id: hal-03090157 \\ https://hal.science/hal-03090157}

Submitted on 29 Dec 2020

HAL is a multi-disciplinary open access archive for the deposit and dissemination of scientific research documents, whether they are published or not. The documents may come from teaching and research institutions in France or abroad, or from public or private research centers.
L'archive ouverte pluridisciplinaire HAL, est destinée au dépôt et à la diffusion de documents scientifiques de niveau recherche, publiés ou non, émanant des établissements d'enseignement et de recherche français ou étrangers, des laboratoires publics ou privés. 


\section{PART III}

Relations between Shicism and Sufism in other Literary Sufi Traditions 


\section{Sufism and Shicism in South Asia:}

\section{Shahādat and the Evidence of the Sindhi marsiya}

Michel Boivin

In one of the first Sindhi-English dictionaries published in 1879 , the word marsiyo ${ }^{615}$ is translated as follows: 'An elegy or dirge, particularly one sung during the Muhorrum'. ${ }^{616}$ In Arabic, the marsiya is an elegy composed to lament the passing of a beloved person and to celebrate his merits. When did the word enter the Sindhi language? Unfortunately, it is not possible to answer but the spread of the marsiya in Sindhi literature didn't start before the 18th century. This paper addresses a double issue. On the one hand, it wishes to introduce the marsiyas from the countryside. What does that mean? In South Asia, the marsiya is associated with the court culture of the main states that have flourished in the ruins of the Mughal empire. The leading school of marsiyas growth in Lucknow, the then capital of the state of Awadh in North India. As a matter of fact, the marsiyas composed by poets such as Mīr Babar 'Alī Ānīs (1216-1290/1802-1874) were considered as the ultimate reference for the writing of these elegies in the whole Indian subcontinent.

Another centre for the production of marsiya literature was the State of Hyderabad, in Dekkan. The marsiyas schools of Hyderabad and Awadh both used Urdu, which was then

\footnotetext{
${ }^{615}$ Although the right word in Sindhi is the masculine marsiyo, I shall use the Persian and Urdu form marsiya (Arabic, marthiyya) which is increasingly predominant even in Sindhi literature. The vernacular words are nevertheless quoted according to the Sindhi language and transliterated according to Ali S. Asani, The Harvard Collection of Ismāi ìli Literature in Indic Languages: A Descriptive Catalog and Finding Aid (Boston, 1992).

${ }^{616}$ G. Shirt, U. Thavurdas and S. F. Mirza, Sindhi-English Dicitionary (sic) (Karachi, 1879), p. 773.
} 
becoming the lingua franca of the majority of Muslims in colonial India. The Urdu marsiiyas have long attracted the interest of scholars, ${ }^{617}$ but the focus they put on urban and Urdu marsiyas gave a distorted image of the art of marsiyas. For the marsiiya genre was also cultivated in peripheral regions where vernacular languages were used for literature, as was introduced as early as 1978 by Christopher Shackle. ${ }^{618}$ In studying the Sindhi marsiya, this chapter wishes to address the issue of the relation between the court culture from the imperial cities and the vernacular expression of the marsiyas. I draw on the common cleavage used in Muslim South Asia between vehicular languages or lingua franca such as Persian and Urdu, and vernacular languages such as Punjabi, Bengali, Gujarati, Sindhi and so on.

On the other hand, it intends to address the issue of the relationship between Shicism and Sufism, an issue which has aleady been addressed in depth mainly in the context of

\footnotetext{
${ }^{617}$ For a synthesis, see J.A. Haywood, 'Marthiya. 4. In Urdu Literature', EI2, vol. 6, pp. 610-612; and Syed Akbar Hyder, Reliving Karbala. Martyrdom in South Asian Memory (Oxford, 2006). Also Andreas D’Souza, 'The Influence of the Rawda-hwāni on the development of Nahwa in the Deccan', in Denis Hermann and Fabrizio Speziale, ed., Muslim Cultures in the Indo-Iranian World (Berlin, 2010), pp. 167-180.

${ }^{618}$ In 1978, Christopher Shackle published a paper on Multani marsiya, and in 2003 a small book on Siraiki marsiya. His work was obviously one of the earliest dealing with the marsiyas out of the scope of Urdu culture. See Christopher Shackle, 'Multani marsiya', Der Islam, 55, (1978), pp. 281-311; Siraiki marsiya (Multan, 2003). Regarding the Sindhi language, a short article was recently published on the depiction of the imām mahdī in Sindhi poetry, mostly based on the works completed by members of the Kalhora lineage who ruled Sindh in the late 18th century; Zulfiqar Ali Kalhoro, 'The depiction of Imam Mahdi in Sindhi Poetry of Sindh (Pakistan)', Rupkatha Journal, 9, 3 (2015), pp. 162-171.
} 
Iran. ${ }^{619}$ The hypothesis is that the Sindhi marsiya is a promising venue for such a study. It allows scrutinising the transformation of the issue of martyrdom in Sufi poetry and finally its role as a motif in Sindhi literature. Finallly, the chapter wishes to shed some light on the complex process through which Shici topics have nurtured the Sufi culture of Sindh, especially through the incorporation of the Shici motif of martyrdom in Sufi poetry. But first, it is necessary to provide some historical context regarding both Shicism and Sufism in Sindh.

\section{Historical Context}

The province of Sindh, which is the southern part of the Indus Valley, was conquered by Muḥammad bin Qāsim, an Umayyad general, in 92/711.Thus, the connection of Sindh with both Sufism and Shicism is ancient, and one point in particular is intriguing: Sindh, located at an edge of the Muslim Empire, was very soon a privileged place for hosting Ghulāt groups. ${ }^{620}$ Sindh is an early land where these shicis had found refuge, for example Muhammad Nafs alZakiyya's son known in Sindh as 'Abd Allāh Shāh Ghāzī (101-156/720-773). Nafs al-Zakkiyya was a great grandson of Hasan, 'Alī's son and the grandson of Muhammad. He claimed the imamate and rose in rebellion against the Abbasid caliph al-Manșūr (r. 136-158/754-775) but he was killed in 145/762. After his death, his followers known as the Muhammadiyya pretended that he was in concealment and would return to fill the earth with justice. A

\footnotetext{
${ }^{619}$ Among the copious literature devoted to this issue, see Henry Corbin, En islam iranien. Aspects spirituels et philosophiques. Tome III. Les fidèles d'amour. Shî̀isme et soufisme (Paris, 1972), pp. $149-375$.

${ }^{620}$ The ghulāt (plural of ghālī), 'extremists' or 'exaggerators', is the name given by the Shici imams and the Muslim heresiographers after them to the Shi'a who divinised Imam 'Alī. See Marshall G. S. Hodgson, 'Ghulāt', EI2.
} 
number among them reached Sindh and 'Abd Allāh Shāh Ghāzī, whose shrine is in Karachi, is supposed to be his son. 'Abd Allāh Shāh Ghāzī’s dargāh is currently the most popular dargāh in Karachi. ${ }^{61}$

Nevertheless, the booklets in Urdu which can be found all around the shrine do not introduce Nafs al-Zakkiyya as a Shici leader, but as a descendant of the Prophet Muhammad. Neither is 'Abd Allāh Shāh Ghāzī introduced as a Sufi. It is said that he was a military commander who died fighting the infidels. It is to be noticed that his sanctity thus does not result from a Sufi affiliation, or from ascetic behavior, but rather from sacrifice, since he died while expanding the dar al-isläm. Furthermore, no source is quoted about his career in Sindh. However, it is interesting to observe that the interaction between a Sufi figure and the issue of martyrdom is already addressed through 'Abd Allāh Shāh Ghāzī’s veneration. Nonetheless, the cult is probably recent and the narratives framing his story may be contradictory. It implies that the figure presently accepted comes from a late reconstruction rather than from attested historical facts.

Another character related to the Ghulāt in Sindh is Muhammad b. al-Ḥanafiyya (d. 81/700). Muhammad b. al-Ḥanafiyya was the third son of 'Alī, but not with Fātịma. He was thus not a descendant of Muhammad. Nonetheless, after Husayn's death in 680, some partisans acknowledged him as the head of the 'Alid family. His followers, known as the Kaysanites, headed by al-Mukhtār (d. 67/687), claimed that Muḥammad b. al-Ḥanafiyya was the mahdi, 'the rightly-guided one', although the word did not yet have eschatological connections since his return was expected imminently and not at the end of time. They also introduced into Islam the themes of occultation (ghayba), and return to life $\left(\operatorname{raj}^{\mathrm{c}} a\right)$.

Mas' ${ }^{\mathrm{u}} \mathrm{d} \overline{\mathrm{i}}$ (d. 345/956) wrote that a number of Muhammad bin Ḥanafiyya's descendants

\footnotetext{
${ }^{621}$ Michel Boivin, Historical Dictionary of the Sufi Culture of Sindh in Pakistan and in India (Karachi, 2015), p. 73.
} 
were settled in Sindh. One of them was the head of a dissident branch of Shicism and he was executed in Multan at the beginning of the 4th/9th century. ${ }^{622}$ According to the Arab historian Ibn Khallikān (d. 681/1282), Muhammad bin al-Ḥanafiyya's mother was a Sindhi. Furthermore, Muhammad Ibn al-Hanafiyya was the hero of the maqtal-nāmas, narratives in which he headed raids in revenge against the authors of the tragedy of Karbala. According to local traditions in interior Sindh, the Amīr Pīr dargāh which is run by the Ismailis is actually the tomb of Muhammad Ibn al-Ḥanafiyya.

In the 19th century, the eldest son of the first Aga Khan, 'Alī Shāh (d. 1302/1885) transformed an obscure saint into a well-known character among the early Shici leaders. In the surroundings of the shrine located in interior Sindh, an inscription gives the date of 1852, without any date in the Muslim calendar. In this period, the first Aga Khan Hasan 'Ali Shāh was living in Bombay, but his son and heir, 'Alī Shāh, was fond of hunting in deltaic Sindh. The reason why 'Alī Shāh decided to dedicate the place to Muhammad b. al-Ḥanafiyya and not to another Shici leader of the early centuries of Islam is unknown. Was he already trying to separate his followers, known as the Khojas, from the Twelver Shicis? As a matter of fact, since Muhammad b. al-Hanafiyya was not acknowledged by the Twelver Shicis, it left a room for non-Twelver Shicis to construct their own distinct genealogy and consequently, tradition. Furthermore, it is well known that in the second half of the 19th Century, the Aga Khans were 'inventing' a new tradition whose main achievement was the rejection of Twelver Shici references. ${ }^{623}$

\footnotetext{
${ }^{622}$ Derryl McLean, Religion and Society in Arab Sind (Leiden, 1989), p. 130.

${ }^{623}$ I have discussed this topic in detail in my book. See M. Boivin, Les âghâ khans et les Khojah: Islam chiite et dynamiques sociales dans le sous-continent indien contemporain (Paris, 2013), pp. 7376.
} 
According to Derryl Mclean, between the middle of the 8th and the beginning of the 12th centuries, the balance between the Sufis and the Shica was in favour of the Shica, although it is not known to what extent such categories are relevant. However, it is probable that fewer than one Muslim out of five was Shici. In the 4th/9th century, the Ismailis spread in Sindh and the province became an Ismaili state under Fatimid suzerainty. After its destruction by Mahmūd of Ghazni (r. 387-420/998-1030) at the beginning of the 5th/11th century, another wave of Ismaili proselytism reached Sindh from the 6th/12th or 7th/13th centuries onwards. Although it is not really attested by local sources, oral tradition states that the Sindhi dynasty of the Sumrās, who ruled Sindh until 1350, was Ismaili. In any case, it is quite probable that after the fall of Alamut (1256) seized by the Mongols, which occurred two years before the fall of Baghdad (1258), the Ismaili imams could have re-activated their oriental network.

Coincidently, in the 7th/13th century, the Ismailiyya were challenged by the Sohrawardiyya settled in Multan and Uch. Bahā' al-Dīn B. Zakariyya (539-631/1145-1234), the head of the Sohrawardīs, sent a number of his family members to Sindh to build a network which is still very active. In the Indus Valley, the Ismailis and the Sohrawardīs used similar strategies of proselytism to win new followers for their respective spiritual leaders. Briefly put, they used to settle in a place inhabited by non-Muslims, most of the time by Hindus often belonging to depressed [the lower ???] castes. They learnt the local language and traditions, and started to compose devotional songs with the local patterns, melodies as well as narratives. They recentred the motifs on the Ismaili or the Sohrawardi spiritual leaders. For example, a song which was devoted to the Devī, one of the figures of the Hindu Goddess, was thus devoted to the imam or to the pir. In addition, with the narration of the many miracles they had performed, part of the local community were gradually becoming followers. Furthermore, the imbrication of the Ismailiyya and the Sohrawardiyya is obvious in a number of polymorphous figures, like that of Pīr Shams, whose shrine is in Multan. 
Another relevant case is that of La'l Shahbāz Qalandar, who is given a double genealogy, Shici and Sufi.

The interrelation between the Sufis and the Shica, especially with those coined as Ghulāt by the Muslim heresiographers, dates back to the coming of the Muslims to Sindh, in the early $2 \mathrm{nd} / 8$ th century. Despite the lack of sources, it can be assumed that such a situation is a main frame for the understanding of the special relation between Sufism and Shicism. On the other hand, the Ismaili Shica and the Sohrawardīs faced each other as soon as in the 7th/13th century. Although their historical relations are not well documented, the Sohrawardīs probably borrowed parts of their esoteric doctrine from the Ismailis. ${ }^{624}$

\section{The Rawdat al-shuhad $\bar{a}^{3}$ and the Issue of Martyrdom in 18th-Century Sindhi Literature} However, there is very little data regarding the spread of Twelver Shicism into the Indus valley and the issue has not yet merited academic attention. An explanation could be the migration from Khurasan of a number of Iranian Shici lineages of sayyids to the Indus valley, such as for example the Sabzwārīs ${ }^{625}$ However, it is not until the 18th century that a new and strong connection appears in Sindh between Sufism and Shicism: Shici devotional literature. This said, some questions are to be addressed: when did Shici devotional literature spread into Sindh? And what was its origin, meaning was it a vernacular production from the starting point, or was it a 'translation' from another literature?

In 1970, Ghulām Rasūl Baloch published the first study devoted to the Sindhi

\footnotetext{
${ }^{624}$ Regarding this, see the pioneering work by Hasan 'Ali Khan, drawing mainly on architecture, Constructing Islam on the Indus. The Material History of the Suhrawardi Sufi Order, 1200-1500 A.D. (London, 2016).

${ }^{625}$ Rubīnah Tarīn, Shāh Shams Sabzwārī sawānah hayāà āwr āthār (Multan, 2007), pp. 33-43.
} 
marsiyas. ${ }^{626}$ He started by introducing the Arabian tradition of marsiyas, followed by the Persian tradition. He understood the marsiyas as a recollection of great figures, turning to the Arabic root of the word. In the same wake [work?], he also quoted Persian poets such as Rūdakī, Firdawsī and others. For him, the first to have written a maršiya understood as an elegy devoted to the martyrdom of the imams at Karbala is Moḥtasham Kāshānī (934996/1528-1588), known as??? Kāshī. As a matter of fact, Kāshānī integrated the pre-Islamic Arabic tradition of marsiyas into the context of the Moharram ceremonies that had received a new impetus under the Shici dispensation of the Safawid state (906-1134/1501-1722). More interestingly, the poem reached the peak of its popularity during the Qajar period, from 1786 onwards.

The next chapter focused on the Urdu tradition, highlighting the role played by Mir Ānīs (Mīr Babar 'Alī Ānīs, 1217-1290/1803-1874), the head?? of what the author named 'urban marsiyas'. ${ }^{627}$ It is true that Baloch's work did not follow academic requirements, and he started with the Urdu marsiyas probably because for him they were the pinnacle of the genre. Nonetheless, the most amazing point is that in the chapter devoted to the Persian marsiyas, Baloch did not mention a main work whose impact on Muslim South Asia is well known, the Rawdat al-shuhadāa ${ }^{628}$

\footnotetext{
${ }^{626}$ Ghulām Rasūl Baloch, Sindhī marsiiya nivesī (Hyderabad, 1970).

${ }^{627}$ ibid., p. 21.

${ }^{628}$ For example, Hyder claims that the impact of the Rawdat al-shuhadāa on the Urdu marsiyas is due to the focus put on the wedding of Qāsim with Ḥusayn's daughter, Sakīna, knowing that weddings were a very popular topic of Indian culture. See Hyder, Reliving Karbala, p. 28. On the issue of the wedding, see also Karen G. Ruffle, 'Karbala in the Indo-Persian Imaginaire: The Indianizing of the Wedding of Qāsim an Fātima Kubrā’, in Denis Hermann and Fabrizio Speziale, ed., Muslim Cultures in the Indo-Iranian World (Berlin, 2010), pp. 181-200, see pp. 181-
} 
Yet, a survey of the manuscript catalogues of the British Library collections shows that the Persian treatise played a leading role in the fabric of Shici devotional production in Sindhi. ${ }^{629}$ The Rawdat al-shuhad $\bar{a}$ ', the 'Garden of the Martyrs', is a Persian martyrology of 'Ali and his family, particularly of Imam Ḥusayn, authored by Ḥusayn Wāciẓ Kāshifī (d. 910/1505). But here again, a number of questions are to be raised: when did it reach Sindh? Was it really a starting point for the writing of marsiyas? No evidence can be found before the early part of the 18th century, knowing that Kāshifī should have written his work at the beginning of the 10th/16th century, maybe in 907/1502. There is thus a gap of more than two centuries.

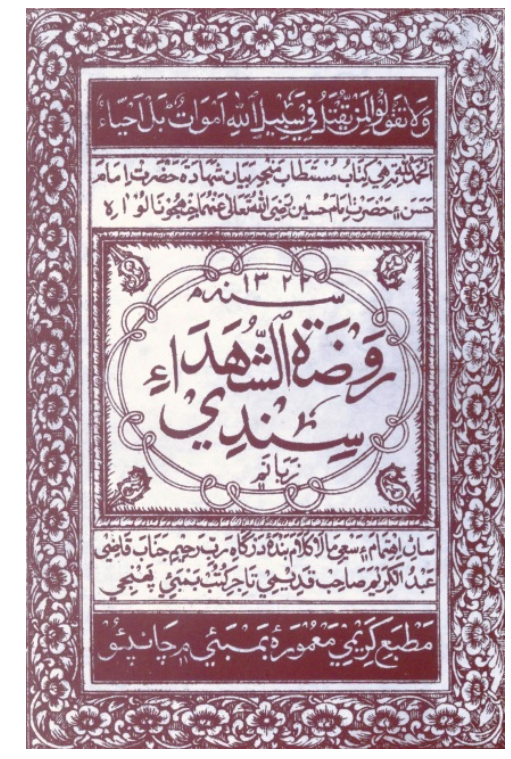

Fig.1 Lithography of the Rawdat al-shuhadā' sindhī, Bombay, 1904 (Baloch, 1992, p. 102)

It should could not be the same as the one on which Memon wrote a few lines in his Sindh ji $\bar{a}$ dabi tārīkh (History of Sindhi Literature). According to him, it would be the first Sindhi

192.

${ }^{629}$ James Blumhardt, Catalogue of the Marathi, Gujarati, Bengali, Assamese, Orya, Pushtu and Sindhi Manuscripts in the Library of the British Museum (London, 1905). 
translation of the Rawdat al-shuhad $\bar{a}^{2}$, by Maulvī Ahmad Marhum in 1212/1798, ${ }^{630}$ knowing that the first Urdu translation was implemented around 1163/1750 by Faẓal 'Alī Fazli ${ }^{631}$ Another manuscript of the 18 th century is a metrical account of the martyrdom of alHasan and al-Ḥusayn, by one Muhammad Hāshim, probably a loose Sindhi translation in verses of the Rawdat al-shuhadāa ${ }^{332}$

On his side, after he had introduced the Arab tradition and the Persian tradition of marsiya, Baloch divided the Sindhi marsiyas in two parts: ancient (qadim) and modern (jadid). He stated that the first Sindhi author of marsiyas is Shāh 'Abd al-Latịf (d. 1165/1752), to whom I shall return. ${ }^{633}$ The most striking point is that Baloch referred to the Rawdat alshuhad $\bar{a}^{3}$ in the chapter devoted to the Sindhi marsiyas: he wrote a few lines on the translation in 'Sindhī dohịrans' ${ }^{634}$ of the Rawḍdat al-shuhadà', adding it was published by

\footnotetext{
${ }^{630}$ Muḥammad Șādiq. Memon, Sindh jī ādabi tārīkh (Shikarpur, 2005), p. 201.

${ }^{631}$ The Urdu translation was titled Karbal kathā (The Narrative of Karbala). According to
} Hyder, it is one of the first prose works of North Indian Urdu. See Hyder, Reliving Karbala, p. 29.

${ }^{632} \mathrm{~J}$. Blumhardt, Catalogue of the Marathi, Gujarati, Bengali, Assamese, Orya, Pushtu and Sindhi Manuscripts in the Library of the British Museum, p. 38. While Kalhoro acknowledges Muhammad Hāshim as one of the earliest Sindhi authors of marsiyas, he did not pay attention to the role played by the Rawdat al-shuhadā'; Zulfiqar Ali Kalhoro, 'The Depiction of Imam Mahdi in Sindhi Poetry of Sindh (Pakistan)', p. 165.

${ }^{633}$ His theory would be supported some years later by Annemarie Schimmel, who wrote a short paper on the Sindhi marsiyas: See A. Schimmel, 'The Marsiya in Sindhi Poetry', in Peter Chelkowski, ed., Ta'zieh: Ritual and Drama in Iran (New York, 1979), pp. 210-221.

${ }^{634}$ The dohịro or dohā is a kind of Sindhi verse, whose shape varies greatly. 
Jamnādās Bhagwāndās, a member of the Hindu literati. ${ }^{635}$

Of course, this does not mean that Kāshifī's work was not known before in the original Persian version but it is not known whether excerpts of it were read before the singing of the marsiyas, as it was performed with the Urdu version in Lucknow. However, it is obvious that the motif of martyrdom was spreading in Sindh since the early 18th century, while it was so to say unknown before, as a literary motif. Among the manuscripts of the British Museum, presently kept in the British Library, there are several versions of 'Ali Akbar's death, al-Husayn's son. One of them, from the 18th century, is an anonymous account of the death of the same 'Ali Akbar. ${ }^{636}$

Amazingingly, the first authors of marsiyas lived during the period when the Sindhi version of Rawdat al-shuhadā ${ }^{3}$ was completed: was there an influence of the second on the first? It is not possible to answer, but it would hardly be a coincidence. Nonetheless, the first marsiiyas were written simultaneously in Persian and in Sindhi, but by different authors. In Persian, the marsiyas were introduced in Sindh by Muhammad Muhsin (d. 1163/1750). Himself a Shici, he authored, among other works, Tirāz-i Dānish (The Royal robe of Knowledge), a maśnawī commemorating the birth of Imam Mahdi. He was following the tarjī’band $^{637}$ in his marsiyas. ${ }^{638}$ But Makhdūm Tharo (d. 1160/1748) had already authored Persian quatrains in which he paid tribute to the Asad Allāh, the Lion of God, the laqab of Imam 'Alī, as well as to the memories of the martyrs of Karbala.

\footnotetext{
${ }^{635}$ Baloch, Sindhī marsizya nivesī, p. 37.

${ }^{636}$ Blumhardt, Catalogue, p. 39.

${ }^{637}$ Tarjī-band is a form similar to that of the ghazal and the qașida, in that the first half of the beginning line rhymes with the second half, but the first halves of the following lines are free from this constraint.

${ }^{638}$ H.I. Sadarangani, Persian Poets of Sind (Jamshoro/Hyderabad, 1987), p. 100.
} 
The spread of marsiya literature in Persian, Urdu and in Sindhi occurred when, after the death of Aurangzeb in 1707, the Indian subcontinent was going through turmoil. The Mughal empire was on the verge of decline. The intestine quarrels between his successors and the growing threat from the Marathas and the Sikhs opened India to new invasions. Nādir Shāh (r. 1148-1160/1736-1747) was to invade the Mughal empire in 1739, followed by the Afghan ruler Aḥmad Shāh Durrānī (r. 1159-1185/1747-1772) in the 1750s. It is tempting to see the development of laments and dirges in the local literature as mirroring the many wars in which the Subcontinent, including the Indus Valley, had felt [suffered???] in the main part of the 18 th century.

Furthermore, the Urdu marsiya blossomed at the same time at the beginning of the 18th century, for example with Muhammad Rafī‘ Saudā (d. 1195/1781), who was patronised by the kings of Awadh. The first ruler of Awadh, Burhān al-Mulk (d. 1143/1731), was himself ethnically an Iranian, and he worked hard for the spread of 'Alid cults in his kingdom. But contrary to the marsiya in Urdu, the Sindhi marsiya was not born in a Shici state, it occurred in the Adil Shāh sultans of Bijapur (894-1097/1489-1686) and the Qutub Shāhs of Golkonda (901-1098/1496-1687), ${ }^{639}$ who were patrons of poetry, and sometimes poets themselves. In Sindh the rulers known as the Kalhorās (r. 1112-1196/1701-1782) were Sunni, and simultaneously affiliated to a local branch of the Sohrawardiyya. ${ }^{640}$ There is no evidence that they they patronised Shici rituals or literature.

In other regions like the Dekkan, numerous poets composed marsiya from the 16 th

\footnotetext{
${ }^{639}$ For a general introduction of the cultural life in the Dekkan sultanates, see R.M. Eaton, Sufis of Bijapur, 1300-1700: Social Roles of Sufis in Medieval India (Princeton, NJ, I978); Shrīrām Sharmā and Mubāraj al-Din Rafat, 'Alī Ādil Shāh kā kāvy-sãgrah (Agra, 1958).

${ }^{640}$ Boivin, Historical Dictionary, p. 220-221.
} 
century onwards, and some even specialised in it. ${ }^{641}$ Like other Urdu poetical forms, the marsiya was at first court poetry, and Haywood claims that because of its religious nature it was taken by princes to the people, to form a corporate religio-literary and social activity. It probably played an important part in the development of the mushāciras (public poetical recital or competition) which became-and still remains-a phenomenon of Indo-Pakistani literary and social life.

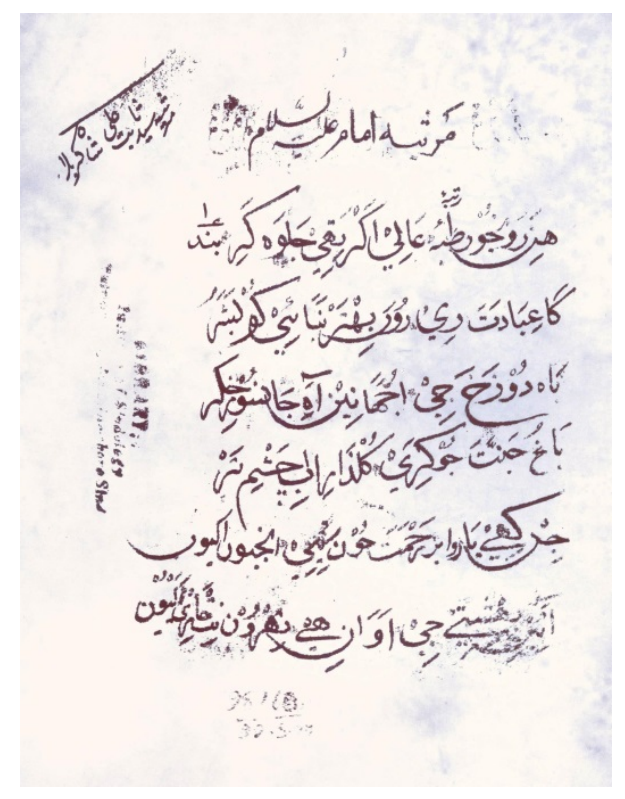

Fig.2 Marsìya imām 'alayhi al-salām, end of 18th century (Baloch, 1992, p. 88)

\section{Sur Kedāro as the Matrix of the Sindhi marsiya}

The life of the first poets of Sindh who authored marsiyas in Sindhi as well as in Persian are not well documented. They could have been court poets, and when they were granted royal patronage, it was not only as authors of marsiyas. However, the birth of the Sindhi marsiya occurred in the countryside. Notwithstanding, a piece of poetry will work as the matrix of

\footnotetext{
${ }^{641}$ Haywood, 'Marthiya. 4. In Urdu Literature', p. 610.
} 
the marsiiya that was inserted in a Sufi work:?? the Shāh jo risālo by Shāh 'Abd al-Lațif (11001165/1689-1752). He was from a Sayyid family settled in Bulri, a small village where his great grandfather, Shāh 'Abd al-Karīm (942-1032/1536-1623), was buried. After years of peregrination, Shāh 'Abd al-Lațif went to settle in a remote part of the interior of Sindh where there was no village. His verses praise the simple life of the peasant.

As Shāh 'Abd al-Lațif is the first to devote a full chapter to Karbala, it is necessary to examine it in detail. My contention here is to decipher the Shici elements. It is an easy task since the Sindhi Sufi poets who preceded Shāh 'Abd al-Lațîf did not use any Shici referent, be it in the lexicon or as a literary motif. ${ }^{642}$ Before starting, it is interesting to mention that it is not known if Shāh 'Abd al-Lațif was Sunni or Shica. It is said that some follower asked him the question. He answered: 'I am between both'. The follower said again: 'But master, there is nothing between?' Shāh 'Abd al-Lațîf stated: ‘So I'm nothing...' Despite the naivety of the story, it highlights a fundamental principle of Sufism in Sindh: Sufism is located beyond religious or confessional, or sectarian, affiliation and belonging.

The Shāh jo risālo is a significant sample of the marsiya from the countryside. It reflects the vernacularised religious culture that flourished in peripheral regions of the Indian subcontinent. ${ }^{643}$ This is a poetry which comes from the very land (desi). More than to master the apex of sophistication in aesthetics as in the courtly culture of North India, the poet wishes to move the simple man of Sindh, a province where a large majority of the inhabitants were landless peasants. Also, the poet speaks directly in his poetry to the groups of local society most discriminated against, such as the dyers (kaprēa) ${ }^{644}$ But since he refers to

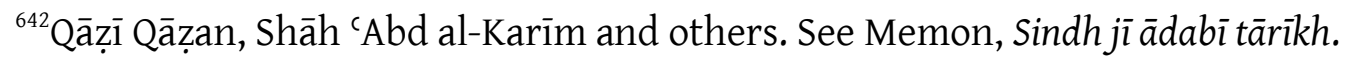

${ }^{643}$ For a more elaborate discussion on the issue of vernacularised religious culture, see Boivin, Historical Dictionary, pp. 12-17.

${ }^{644}$ In 18 th-century Sindh, social organisation was very much influenced by the caste system.
} 
folk narratives and heroes shared by all creeds and traditions, all Sindhis felt involved in Shāh 'Abd al-Laṭif's poetry.

The Shāh jo risālo consists of 30 chapters, each centering around one topic and traditional tales which are mystically interpreted and sung in a specific melody, a sur. The Sindhi word sur is more or less the equivalent of rāga, namely a musical mode which is to express a given feeling, and/or to be played at a given moment of the day. In the Shāhjo Risālo, there is a sur which of special interest, Sur Kedāro. In Sindhi, the word kedaro means war. It comes from a Sanskrit term with same meaning of war. In classical Indian music, the rāga Kedār is said to be associated with the god Shiva and is to be sung at mid-day. Furthermore, it is also a contemplative rāga and it is represented as an ascetic who is deeply absorbed in meditation. In the 17th century, the rāga Kedār was one of the main rāgas performed at the Mughal court (The Raga Guide, 1999: 5).

In the Shāh jo risālo, Sur Kedāro is thus the chapter on war. The whole chapter is devoted to the martyrdom (shahädat) of the third Shici imam, Husayn, who died in 680 at Karbala with many of his family members. A thorough study has yet to be made on the reasons for which Shāh 'Abd al-Lațif introduced a Shici topic in his poetry. However, this is something which distinguishes him from his predecessors in classic Sindhi Sufi poetry. One might think that it could be due to influence from Persia where the marsiya genre, the dirge devoted to the martyrdom of Husayn and his family, was booming. The narrative of the Karbala tragedy did not, however, strictly follow the shape of the Persian marsiya.

The main argument of Sur Kedāro is that the experience of martyrdom is the experience of meeting God. Subsequently, a sacrifice, regardless of its shape, is necessary to reach God. Sur Kedāro is divided into six parts addressing four main issues. First is the coming of Moharram, the month of mourning of martyrdom of Husayn b. 'Alī, a trial of their love.

Groups such as the dyers belonged to the untouchables, who were considered impure. 
Second is the apparent helpless state of the imams. The third part is about their bravery in fighting and the fourth part deals with their union with God after death. As in other poetry, Shāh 'Abd al-Lațif involves the natural elements in the grief resulting from the martyrdom of Husayn, when it is said for example that on the last day, the 10th of Moharram, the sky darkened. Animals can also play a leading role. For example, a bird (paki) carried the message of the martyrdom to the Prophet's mausoleum in Medina. It could be a reminiscence of the Rawdat al-shuhada $\bar{a}^{3}$ where it is a pigeon that is the messenger.

Shāh 'Abd al-Lațif's depictions of the different episodes of the battle are made very vivid with precise details. In the first part, he starts by giving a detailed description of the weapons. The poet also points out the bravery of the Imam's party, as well as of the women, especially when he explains how they faced the death of their husbands. In the fifth part the most heartbreaking passage is the depiction of Imam Husayn's end. The red colour, which dominates the narratives through different nuances, has invaded the battlefield and the desert. Even the hoofs of Duldul, the name given to Husayn's horse, ${ }^{645}$ are all red. Finally the Imam himself is turning red:

With blood his beard became crimson red;

His teeth appeared red like a rose, as they profusely bled.

Like the full moon on the fourteenth night, His majestic turban shone, clear and bright. ${ }^{646}$

\footnotetext{
${ }^{645}$ Amazingly, Duldul is the name given here to Ḥusayn's horse at Karbala, although usually it is the name of 'Alī's horse. Nowadays, as least in the processions of Moharram, Husayn's horse is called Żul Jināḥ.

${ }^{646}$ Ghulamali Allana, Four Classical Poets of Sind (Jamshoro, 1983), p. 70.
} 
The concept of martyrdom is a key concept which links Shicism and Sufism. Husayn’s martyrdom is the matrix from which the martyrdom of Sufis will be depicted, like Manșūr alḤallāj (d. 302/922) or Shāh 'Ināyat (d. 1130/1718), to whom I will return. After providing the dramatic feeling of Karbala, Shāh 'Abd al-Lațif reaches his central statement when he sings: The hardship of martyrdom (shahādat), Listen!

Is the day of wedding (shādī)

This statement which assimilates shahādat with shādī is reminiscent of death symbolised as the merging of the Sufi in God: the 'urs, which also means wedding. In another verse, shāh 'Abd al-Latịf claims: 'The rend understand the secret ( $r \bar{a} z)$ of Karbala'. It reinforces the identification of the Sufi, with Husayn, and thus the link between Sufism and Shicism. It is interesting to note that Shāh 'Abd al-Lațif uses the word rend, and not faqiir or any other. It refers to Sufis who are embedded in a tarīqa, limited by a specific ādab. The rend, or the qalandar, is the one whose desire is only one, to be merged with God. Simultaneously, the rend is therefore the only one who can understand properly what occurred at Karbala. The use of this terminology is rare in Shāh 'Abd al-Lațif's lexicon. Maybe it is a kind of reminiscence of a powerful Sufi saint of Sindh, Lal Shahbāz Qalandar (d. 672/1274), since he himself uses the word rend in his Persian poetry. ${ }^{647}$

\footnotetext{
${ }^{647}$ Lacl Shahbāz Qalandar (d. 672/1274) is said to be the descendant of Ismacil, the sixth imām Ja‘far al-Ṣādiq's son who was acknowledged as imam by his followers thus known as Ismailis. He was himself a qalandar and as such, he travelled in the heartland of the Islamic world, before reaching the Indus Valley soon after the Mongol intrusion. He finally settled in Sehwan Sharif, in Sindh, and his mausoleum is one of the most popular in Pakistan. A number of artefacts which are currently worshipped [revered ???] on different occasions relate him with Shici sacred figures, as for example the fourth imam Zayn al-`Abidin. See Michel Boivin, Artefacts of Devotion. A Sufi Repertoire of the Qalandariyya in Sehwan Sharif, Sindh
} 
In another verse, Shāh 'Abd al-Latịif says: 'The Friend (dust) kills the beloved, the lovers are slain'. Here again, Karbala tragedy is depicted with Sufi terminology. In the last part of Sur Kedāaro, Husayn is described as the bridegroom (ghoț), a topos of Sindhi Sufi poetry which is most of the time attributed to Muhammad: 'With flower-embroidered dress, o man, be prepared for the wedding'. The bridegroom has decorated his horse, as in Sindhi custom, and he rides for his fatal battle. The issue of the ghot is also addressed in regard to Qāsim, who was to be married before he died. A passage of the sur pictured him with his uncle Husayn. The latter asks him to rescue his companions and he comes in his beautiful bridegroom garments. In another passage, the word ghot (pl. ghotan) is given to all the companions who, besides Husayn, are to die as martyrs. There is a beautiful and tremendous description of the final part of the battle, when the ghots and their horses (ghotan ghoran) are all intermingled in the savagery of the battlefield.

The metaphor of the wedding is therefore crucial for the integration of Shici elements in Shāh 'Abd al-Lațif's Sufi poetry. The chapter ends with a meaningful verse in which the integration is achieved:

'They have become annihilated in God, with Him they have become He'.

Shāh 'Abd al-Lațîf employs the Arabic expression fanā' fì'llāh which is, interestingly, coupled with, and thus reinforcing, the Sindhi version of fāni thiya. The poet carries his argument through associations since he started by associating shahādat with shā $\overline{\bar{l}}$, and he ends the sur in associating shahādat with fanā'. In concluding Sur Ked $\underline{a} r o$, Shāh 'Abd al-Lațîf exhorts God to provide him the vision of the martyrs, in a typical Sufi mood. It is noteworthy that here, he doesn't use the Persian word dìdār, although one can find it in other surs, but the very Sindhi

(Pakistan) (Karachi, 2011), pp. 94-95. 
verb dekhāran. In referring to this main Sufi achievement, Shāh 'Abd al-Lațîf definitively embodies Shici elements into Sufi poetry.

Briefly put, Shāh ‘Abd al-Lațîf expresses Ḥusayn's martyrdom (shahādat) with the Sufi lexicon and main trope. In this respect, it is relevant to see it as the Sufi poet's attempt to capture the emotion of Karbala, as if reaching fan $\bar{a}^{\jmath}$ fìllāh was only possible by performing a self-sacrifice. Husayn's shahādat thus works as a metaphor whose aim is to prove that fana $\bar{a}^{3}$ fi'llāh cannot be realised without the sacrifice of the self. Along the way, he merged Husayn's shahädat with that of a number of Sufis who sacrificed their lives in different circumstances.

Devotional literature in Sindhi gives evidence of how Shicism and Sufism are interwoven there. It appears that Shāh 'Abd al-Lațif uses Sufi terminology to describe the tragedy of Karbala. Furthermore, the main achievement of his verses is the identification of Husayn with Sufi figures, martyrs and others. It is possible that the identification process of Husayn with a Sufi figure has been reinforced by historical circumstances, both regional and South Asian at large.

\section{The marsiya as a Genre of Sindhi Poetry}

Regarding regional history, a major event occurred in 1197/1783: a Baluch clan, the Ṭalpūrs, seized power and interestingly, founded a state which was divided into three distinct territories, each of them ruled by a king ( $m i \bar{r}$ ) established in a separate capital, at Hyderabad in Sindh, Khairpur and Mirpur, presently known as Mirpur Khas. Almost all the Talpūr princes of Sindh were Twelver Shicis. Not only did they patronise Shici rituals as well as Shici buildings such as the imāmbārās, ${ }^{648}$ but a number of them wrote marsiiyas and other poetry.

\footnotetext{
${ }^{648}$ In Sindh, the imāmbārā is the building where sermons are delivered during the first ten days of Moharram, and where the different artefacts which are paraded are kept.
} 
The first author who was specialised in writing marsiyas in Sindhi is Thābit 'Alī Shāh (d. 1224/1810). He was twelve years old when Shāh 'Abd al-Latịf passed away. Thābit 'Alī Shāh was born in Multan, but settled in the holy city of Sehwan Sharif with his father Madar 'Alī Shāh. He was a sayyid who wrote poetry in Persian, Urdu and Sindhi. He was patronised by the Talpūrs and lived at the court of Hyderabad. It was at the expenses of the king that he was able to make a pilgrimage to Karbala and the shrines of all the imams. In 1805, he was sent by the mīr of Hyderabad as an ambassador to the king of Persia, Fatḥ 'Alī Shāh Qājār (d. $1249 / 1834)$.

His marsiyas are usually filled with Persian and Arabic expressions and terms but he also produced pure Sindhi poetry. They are still sung during the procession of Moharram in the main cities of Sindh. Furthermore, Thābit 'Alī Shāh is also the author of a madāḥ, praise to a saintly figure, devoted to La'l Shahbāz Qalandar, which is sung for 'Alī's birthday inside his shrine. His marsiyas move both Muslims and non-Muslims to tears. Although he composed some verses on the martyrdom of the Imams in Persian, he was nicknamed the 'Ānīs of Sindh' for his Sindhi marsiiyas. In his verses which follow generally the form aaabb, Thābit 'Alī Shāh uses all the references of the genre, naming Ṣaḥab Duldul, 'Alī's horse, and focusing mainly on the fate of 'Alī Akbar, one of Husayn's sons. He praises the sacrifice (qurbān) they have performed and often quotes the famous Là fatā illa 'A Alì là sayf illà dhū'lfaqār, 'there is no hero except 'Alī, there is no sword except dhū'l-faqār ${ }^{6}{ }^{649}$

From the time of Thābit 'Alī Shāh, the marsiiya was a genre of Sindhi poetry. Richard Burton is probably the first to mention it as one of the four genres with madāh, munājāt and lānat which

\footnotetext{
${ }^{649}$ Baloch, Sindhì marsìya nivesì, p. 53. The word dhū'l-faqār is the name of 'Alī's sword. Regarding the word fatā or javānmard in Persian, see Mohsen Zakeri, 'Javānmardi', EIR, vol. 14, pp. 594-601.
} 
are 'common to all the Moslem world', to which he added five others 'more original' ${ }^{650}$ After the fall of the Talpūrs in 1258/1843, other leading Shici families patronised the authors of marsiyas, or sometimes they themselves authored marsiyas, without these always being published. A good example is that of Makhdūm Muhammad Zamān Ṭāleb al-Mawlā (19191993), a scion of the powerful khāndān of the Makhdūms of Hala. ${ }^{651}$

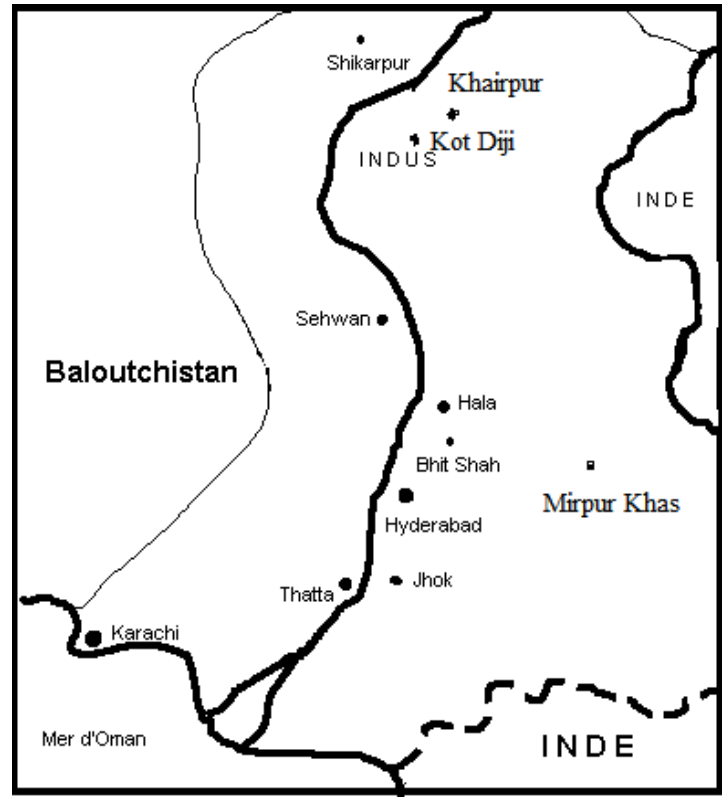

Fig.3 Sindh showing the main places mentioned

The spread of a vernacular form of the marsiyas did not prevent the existence of a courtly

${ }^{650}$ Richard Burton, Sindh and the Inhabitants of the Indus Valley (Karachi, 1851), pp. 78-79.

Interestingly, Nabi Bakhsh Baloch classified marsiya among the devotional songs with madāh, munājāt mawlūd, but he didn't publish any of them, contrary to the other three categories: Boivin, Historical Dictionary, p. 95-96.

${ }^{651}$ Makhdūm, no date. The Makhdūms of Hala are the descendants of Makhdūm Nūh, a Sohrawardī Sufi who played a leading role in 16th-century Sindh, working as a scholar of Islam, and also as a mediator with political power. See M. Boivin, Historical Dictionary of the Sufi Culture of Sindh, pp. 206-208. 
marsiya expressed in Persian. It does not seem that the Persian marsiyas were very common in Sindh before the 19th century. After the Talpūrs were defeated by the British in 1843, the states of Hyderabad and Mirpur Khas were suppressed; the state of Khairpur was thus the sole princely state of Sindh ruled by a Shici Țalpūr up to 1955, when it was incorporated in Pakistan. During British colonisation, Khairpur became a hotbed of Shicism in Sindh. In the last decades of the 19th century, especially during the long reign of Mīr 'Alī Murād (r. 12571311/1842-1894) and that of his successor, Mīr Faīz Muhammad (r. 1311-1326/1894-1909), magnificent palaces were built, such as the Faizi Mahal, as well as beautiful imāmbārās and ta $^{c}$ zias ${ }^{652}$ mainly in the capital, Khairpur, and in Kot Diji, another main residence of the mirs. ${ }^{653}$

As Sadarangani pointed out, since the Shici Țalpūrs broadly patronised poetry, many Sunni poets wrote in praise of Imam 'Alī and the martyred imams: 'In the circumstances it becomes difficult for the reader to determine from the works of a poet of the Talpūr Age whether he was a Sunni or a Shica (...)'. ${ }^{654}$ Mīr Nāṣir Khān Ṭalpūr (d. 1260/1845), a son of Mīr Murād Alī Khan the mìr of Hyderabad, was nonetheless himself a Shici who wrote with the pen name of Ja'farī. After the British conquest, he was exiled like all the Talpūr princes. He stayed in Calcutta and longed to be buried in Karbala instead of Bengal. In his verse, Ja'farī still echoes the assimilation of martyrdom with the wedding with God: 'The blood of the self-

\footnotetext{
${ }^{652}$ In South Asia, $t a^{c} z \bar{i} a$ is the name given to the replica of the tomb of Imam Husayn carried in procession during Moḥarram.

${ }^{653}$ Interestingly, the craftsmen belonged to Hindu castes from Jodhpur, in neighbouring Rajputana (nowadays Rajasthan), and Bahawalpur. Regarding architecture, it is said the Țalpūrs were influenced by their Northern neighbours, the Sikhs of Punjab, particularly the famous architect Bhai Rām Singh.

${ }^{654}$ H.I. Sadarangani, Persian Poets of Sind (Jamshoro, Hyderabad, 1987), p. 152.
} 
sacrificing lover is henna for the beloved's hands!'

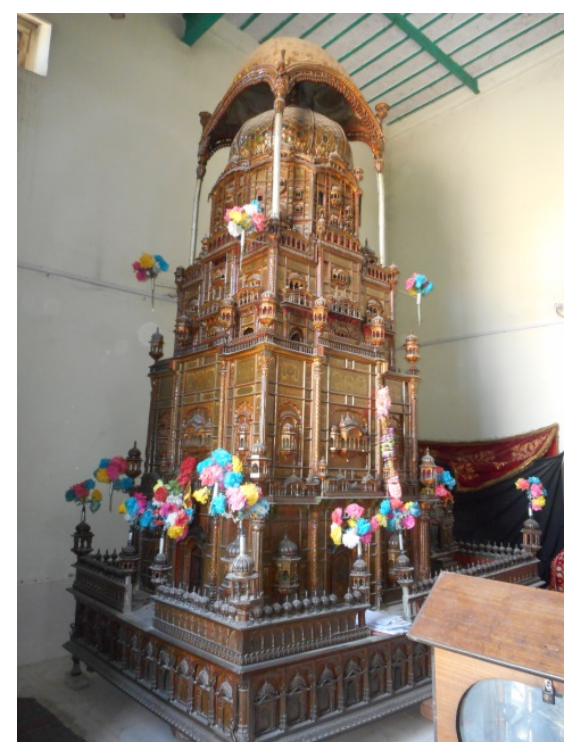

Fig.4 A ta'zia kept by the Ṭalpūrs in Kot Diji, late 18th or early 19th century (@Michel Boivin, 2014)

Despite the dwindling of patronage after the British took control of Sindh, the Talpūr school of Persian poetry did not end. However, there was no special literary form used for the lament. In this context, the use of the word marsiya comes from the overall topic rather than from a literary genre. Also, one can find hardly any works that are devoted totally to martyrdom. The best example of this trend is Mīr Sābir 'Alī (d. 1264/1868) who praised 'Alī in his verses, figured as Shah-e mardān, to reach self-realisation. One could say it was thus the most common trope of Persian poetry of Sindh in general.

\section{Sachal Sarmast and the Junction of Ḥusayn's shahädat with the Sufi figure of the Martyr}

During the last days of Mughal domination in Sindh a Sufi, Shāh 'Ināyat (ca 1032-1123/ca 1623-1712), rose to prominence. He travelled around India, and was initiated into the Qādiriyya and the Sohrawardiyya in Bijapur or Burhanpur. He settled into a life of devotion 
to God in the village of Jhok, not far from Thatta but on the eastern bank of the Indus River. His reputation of being a high-level mystic spread all around Sindh and in Jhok he provided free land to the peasants who quickly flocked to the place. The bonded farmers of many of the local landlords reached Jhok.

In $1126 / 1715$, the sayyids of the neighbouring villages were given permission by the Mughal governor of Thatta to attack Jhok. Many of the dervishes sacrified their life for their master, Shāh 'Ināyat. In 1127/1716, a new Mughal governor was posted in Thatta after which the Kalhoras took northern Sindh under their control. Yār Muhammad Kalhoro was keen to expand his control throughout Sindh. In the summer of 1128/1717, he started a campaign against Jhok, probably with the consent of the Mughal governor. In January 1129/1718, Shāh 'Ināyat decided to surrender to spare the life of his dervishes. He was executed and his head was sent to Delhi. ${ }^{655}$

Shāh 'Ināyat's martyrdom gave birth to many legends in Sindh. The Sohrawardī Sayyid Mīr Jān Muhammad from Rohri (d. 1167/1754) clearly alluded to Shāh 'Ināyat's martyrdom. ${ }^{656}$ He was present at Jhok when it was decided to put him to death. Many other Sufi poets will echo the tragic event in the late 18th and early 19th centuries. Of course, it is not possible to claim it can explain the spread of Kāshifī's work on the martyrdom of Karbala. It is nonetheless undeniable that his martyrdom paved the way for the incorporation of marsiiyas into Sufi poetry.

Another Sufi poet was a follower of Jhok Sharif. Dalpat Ṣūfī (1769-1842) was a Hindu from Sehwan Sharif. He belonged to the Merānī family who used to perform the mendī

\footnotetext{
${ }^{655}$ See a detailed description of Shāh 'Ināyat's martyrdom in Schimmel's pioneering work: Annemarie Schimmel, Pearls of the Indus. Studies in Sindhi Culture (Jamshoro, Hyderabad, 1985), pp. 156-165.

${ }^{656}$ Sadarangani, Persian Poets of Sind, pp. 102-103.
} 
ritual ${ }^{657}$ for the death anniversary of Lacl Shahbāz Qalandar. Dalpat regularly visited Jhok Sharif but he spent the last years of his life as a recluse in Hyderabad. His Sindhi poetry is still much acclaimed in Pakistan and in India. In Persian, he wrote a mathnawi entitled Jang Nāma where he deals with the martyrdom of Shāh 'Ināyat as well as with the different phases of the struggle for the eradication of the nafs-e āmāra, the lower or carnal soul, otherwise known as jihād-e akbar, the biggest fight. ${ }^{658}$ To some extent, one can surmise Dalpat gave a renewed version of the Sur Kedāro where Shāh 'Ināyat seizes the figure of Imam Ḥusayn, knowing the main issue is to introduce martyrdom as the fanā' fì'llāh. However, Shāh 'Abd alLațif's language is far more sophisticated that Dalpat's. The latter wrote in simple and very clear Sindhi and he thus contributed to the massification of the issue of shahādat among the Sindhis.

Throughout the decades, many hints show that Kāshifī's work was still a main reference regarding the issue of martyrdom in Sindhi poetry. Still in 1278/1862, the Rawdat al-shuhadā $\bar{a}^{3}$ was translated into Sindhi as found in a manuscript kept by the Khojas, the followers of the Aga Khan [I]..$^{659}$ The Khojki ${ }^{660}$ collection of Harvard University provides many samples with marsiyas devoted to the imams or their family members, such as Qāsim, Hasan's son who was to marry Ḥusayn's daughter. Others are devoted to 'Alī Asghar or 'Alī Akbar, and even to female figures such as Bībī Khānūm or Sakinna. ${ }^{661}$ Other marsìyas deal with the

\footnotetext{
${ }^{657}$ The Sindhi word for henna, a main symbol of a wedding in South Asian culture. As noted above, a saint's death is represented as his wedding with God.

${ }^{658}$ Sadarangani, Persian Poets of Sind, p. 204.

${ }^{659}$ Asani, The Harvard Collection, p. 80.

${ }^{660}$ Khojki is the name given to the script used by the Khojas. It belongs to the Landāor 'clipped' scripts used by merchant communities in Sindh and in Punjab.

${ }^{661}$ Asani, The Harvard Collection, p. 164-166.
} 
martyrdom of some direct ancestors of the Aga Khans. For example, there is a marsiya on Shāh Khalil Allah, the first Aga Khan's father, who was assassinated in Persia in 1232/1817. Interestingly, there are also devotional pieces known as vāvillās, the Sindhi word for lament, which are attributed to the first Aga Khan, Hasan 'Alī Shāh (d. 1298/1881). In the beginning of the 19th century, the Khojas were among the specialists of marsiyas in Sindh. According to Richard Burton: 'They are fond of the Marsiyas, or elegiac poetry on the subject of Hasan and Husayn's martyrdom; such compositions are common among them (...)' ${ }^{662}$ In this case, it is interesting to see that although Kāshifī still works as a model, simultaneously, the marsiyas were re-oriented to serve the Aga Khan's policy which was to take control of the Khoja caste. ${ }^{63}$

In parallel with Shāh 'Inayāt's shahādat, another Sufi martyr was framed into a pattern. According to local historians, a famous martyr paid a visit to Sindh in the early 10 th century: Manșūr al-Ḥallāj (d. 309/922), who died on the gallows in Baghdad because he said publicly that he was God: anā al-haqq (lit. 'I am the Truth') in Arabic. Officially, he was accused of being a heretic but the mystics as well as the common people in Sindh claim that it was because he had reached the divine stage. According to Schimmel, Hallāj's importance was highlighted first in the lines of the Qādirī mystics, ${ }^{664}$ but in Sindh, the motif could have known a new dynamic with the shahādat of Shāh 'Inayāt. Ḥallāj was probably a popular figure but nonetheless, it is with Sachal Sarmast (1151-1241/1739-1826), himself a Qādirī, that he was transformed into a trope of Sufi poetry. ${ }^{65}$ Although he didn't die on the gallows, Sachal

\footnotetext{
${ }^{662}$ Burton, Sindh and the Inhabitants, p. 250.

${ }^{663}$ Boivin, Les âghâ khans et les Khojah.

${ }^{664}$ See the paper Schimmel has devoted to the issue: Schimmel, Pearls of the Indus, pp. 87-149.

${ }^{665}$ Sachal Sarmast authored poetry in a number of languages such as Persian, Hindustani, Siraiki and Sindhi. I use here his work in Sindhi: Sachal Sarmast, Risālo Sachal Sarmast (Sindhī
} 
Sarmast was known in Sindh as 'Manșūr Thānī’, the second Manșūr.

Sachal is considered by Baloch to be an author of marsiyas belonging to the old school. ${ }^{666}$ In his verses, Sachal highlighted the bravery of Husayn and his companions and relatives. He also praises Qāsim's wedding as a prelude to the marriage of the martyr with God. All these references can be seen as reformulations of Shāh 'Abd al-Lațîf poetry. Nonetheless the innovation he brought concerns the assimilation of Hallāj's death with Husayn's martyrdom. The most striking point is that the focus is put on the martyrdom itself, as if it was a new shape of Husayn's shahādat. Sachal Sarmast associates the state reached by Hallāj with a triumph. It is thus clear that divinity is the finality of the Sufi path. He also pointed out that sacrifice is but a sine qua non condition to reach the state of divinity: My head I am ready to sacrifice Like this will suffice $e^{667}$

Sachal was only the first of many Sufi poets who referred to Hallāj's martyrdom, such as Bedil (d. 1288/1872), his son Bekās (d. 1299/1882) or Rakhiyyal Shāh (d. 1358/1940). Once again, martyrdom is a trope of Sufi poetry in the 19th century and other Sufi poets also tried to associate the martyrdom of Hallāj with that of Ḥusayn. The construction of Hallāj as a trope attracted the interest of a Hindu from Sehwan who published a biography in $1915 .^{668}$ In the mid-19th century, Faqīr Qādir Bakhsh (d. 1288/1872), better known as Bedil, was a Qādirī Sufi from northern Sindh who wrote a pastiche in Persian of the famous Rawdat al-shuhad $\bar{a}^{\prime}$. Bedil composed poetry in Sindhi, Siraiki, Urdu and Persian. He also wrote Sindhi

kalām), ed. 'Umān 'Alī Ānșārī (Kandiyaro, 1997).

${ }^{666}$ Baloch, Sindhī marsìya nivesī, pp. 43-44.

${ }^{667}$ Allana, Four Classical Poets of Sind, p. 105.

${ }^{668}$ Deumal Arumal Sehwānī, Manșūr jī hayātī (Hyderabad, 1915). 
marsiyas, and consequently he is well represented in Baloch's anthology. His verses are very simple such as:

When Shāh as a guest (mehmān), appeared at the battleground of Karbala, The wave of grief (dard) and agony (gham) highly prevailed there! ${ }^{669}$

In his verse, Bedil reproduces the associations operated by Shāh 'Abd al-Lațif whose aim is to implement a fusion between both figures, the Shici imam and the Sufi. He even reinforces the mystical interpretation of Karbala in diminishing the very real depiction of the battle, the wounds, the bleeding of the fighters etc. He proceeds in putting together opposite couples of feelings, such as sadness (soz) and love (piyār), or pain (dard) and love (dil). ${ }^{670}$ The goal is to show Karbala's lesson that pain and sadness are but a step on the way of divine love.

\section{Mīrzā Qalīch Beg and the Final Bridging of Shicism and Sufism}

While the trope of shahādat was incorporated with Sufi poetry, the spread of the marsiyas as a distinct literary genre did not end. A Ṭalpūr mīr, Ḥasan 'Alī Khān (d. 1324/1907), was an author of fine marsiyas where he mostly focused on shahidan jo gham, the word gham referring to the last part of the majlis, when the narrative gives the more striking details of the martyrdom, inducing tears of grief in the audience. ${ }^{671}$ Another Ṭalpūr, Mīr ${ }^{C} \mathrm{Abd}$ alHusayn Sangī (d. 1342/1924) also composed marsiyyas although his work is composed mostly of ghazals. He was the grandson of the last mìr of Hyderabad, Mīr Nāṣir KhānṬalpūr, who was

\footnotetext{
${ }^{669}$ Baloch, Sindhì marsizya nivesī, p. 64.

${ }^{670}$ ibid., p. 68.

${ }^{671}$ ibid., p. 74.
} 
defeated by General Napier at the battle of Miani in 1258/1843. The final incorporation of Shici shahādat as a trope of Sindhi poetry is obvious with the work of a Hindu poet, Parsrām Ziyāà (d. 1377/1958), where one can find reference to Imam Ḥusayn’s martyrdom.

At the beginning of the 20th Century, the mirs of Khairpur were among the leading figures of the Indian Shici community. In 1928, Mīr 'Alī Nawāz Khān Ṭalpūr, whole ruled Khairpur from 1921 to his death in 1935, was the president of the All India Shica Conference held in Calcutta, and as such, he was asked to deliver the presidential address. Since the late 19th century, the mìrs of Khairpur had patronised the building of imāmbārās, following the mainstream process centred on Lucknow, tagged by Justin Jones as the building of a 'Shici qawm', namely a distinct Shici community. Some of the Shicis went so far as to publicly oppose what they saw as the Sunni-run Muslim League. ${ }^{672}$

Mīrzā Qalīch Beg (1853-1929), a leading member of the literati of Sindh, was close to the mir, himself a Shica. He was a member of the Anjuman Shica Conference, a local branch of the All India Shi`a Conference, and Mīr 'Alī Nawāz Khān invited him several times to be his wazìr or prime minister but he politely declined the offer. Mīrzā Qalīch Beg was probably the first scholar to take an interest in Shici devotional literature in Sindhi. Knowing the involvement of both Mīr 'Alī Nawāz Khān and Mīrzā Qalīch Beg, through their membership of the anjumans, one can surmise that their concern was to locate the Shicism of Sindh in the

\footnotetext{
${ }^{672}$ On the construction of a 'Shici qawm' in North India, see the detailed analysis in Justin Jones, Shi`a Islam in Colonial India: Religion, Community and Sectarianism (Cambridge, 2011). Regarding the representation of the Shica in the Muslim League, a number of them were among the founders of the organisation in 1906, such as Sulțān Muhammad Shah, the third Aga Khan. Later on, their number decreased but this issue is still to be investigated. On the early years of the Muslim League, see Francis Robinson, Separatism among Indian Muslims, 18601923 (Cambridge, 1974).
} 
wake of this Shici reappraisal.

As a matter of fact, in 1925 Mīrzā Qalīch Beg was the first editor of Śābit 'Alī Shāh's work (diwān), mostly comprised of marsiyas. ${ }^{673}$ The title was simply Marsiya Thäbit ' $A l i \bar{S}$ Shāh jā, or The Marsiya of Śäbit 'Alī Shāh. ${ }^{674}$ The process of shifting such a poetry genre from the oral corpus, unless manuscripts had been copied, to a published corpus, obviously has a manifold meaning. It occurred more than half a century after the first Sindhi poetry was published, the famous Shāh jo risālo, in 1866. Being Shici was thus not an issue in Sindh prior to the 20th century. The main impact of publishing Sāait 'Alī Shāh's marsiyyas was both to represent him as the Ānīs of Sindh, and to anchor the Shici community into a unique devotional corpus with which they can be identified. This construction didn't prevent the process of incorporating Shici elements in Sufi poetry in which Mīrzā Qalīch Beg played a leading role.

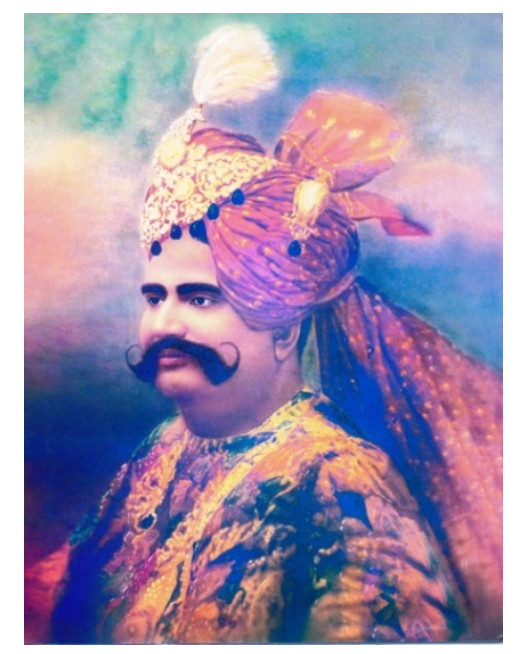

Fig.5 Mīr 'Alī Nawāz Khān Ṭalpūr (1884-1935) was mīr of Khairpur from 1921 to 1935

\footnotetext{
${ }^{673}$ Memon, Sindh jiādabi tārìkh, p. 162.

${ }^{674}$ Baloch, Sindhi marsiya nivesī, p. 102. Nothing more is known about it, and needless to say I was not able to see a single copy.
} 
Apart of the marsiiyas he had himself written, ${ }^{675}$ Mīrzā Qalīch Beg published in 1929 a compilation of Sindhi salāms and nohās titled Tuhfah-i imāmiyah, The Gift of the Imāmites. ${ }^{676}$ Consequently, after he had edited Ṡābit 'Alī Shāh's marsiyas, he felt the need to focus on a more popular type of Shici literature, which referred to the majlis itself, which is the commemorative assembly. ${ }^{677}$ The salāms are the salutations or benedictions, used especially in the context of the majlis as an identity marker of the nascent Shici qawm to refer to the opening part. The nohās are elegies commemorating one of the martyrs of Karbala, mainly chanted during the matām, when the devotees beat their chests. This title is the one given in the British Library catalogue, while the title of the copy kept by the Institute of Sindhology, University of Sindh, Jamshoro, does not include salām 'ain nohāa, However, there is no place and the date as stated in the introduction is 1919, instead of 1929 as it is put in the British Library copy. [repeated in the footnote below]

However, the copy of the Institute of Sindhology does not include any salām or nohā. The book is mostly a compilation of marsiyas, almost $80 \%$ of the whole, dedicated to the main characters of the Karbala tragedy, including Ḥusayn, 'Abbās, 'Alī Akbar, 'Alī Asghar and others. There are other poetic genres, such as $r u b \bar{a}^{c} \bar{i} \bar{a} t, n a^{c} t$, or manaqib. The book ends with different khutbas, including one for 'id ghadir, and finally the $d u^{c} \bar{a}$ of the Twelver Shicis in

\footnotetext{
${ }^{675}$ ibid., pp. 94-96.

${ }^{676}$ Mīrzā Qalīch Beg, Tuhfah-i imāmiyah: salām 'ain nohāa (Shikārpūr, 1929). This title is the one
} given in the British Librany catalogue. The copy I have examined is that of the Institute of Sindhology, University of Sindh, Jamshoro. The title does not include salum cain nohis, especially since it does not include any... However, there is no place and the date as stated in the introduction is 1919, instead of 1929 as it is in the Dritish Librany copy.

${ }^{677}$ The majlis is a commemorative assembly held in honour of the martyred members of the Prophet's family. 
Sindhi.

Mīrzā Qalīch Beg's publications on Shicism in Sindhi were a new building-block in the development of the Shici qawm of Sindh. Beyond his interest into Shici devotional poetry, Mīrzā Qalīch Beg played a fundamental role in the ongoing process of integrating Shici tropes in Sufism. He could thus not depart from what was the main characteristic of Shicism of Sindh, its entanglement with Sufi poetry. In his Lughat Lațifi, he gave the most important words and expressions of the Sur Kedāro with a Sindhi explanation. It shows a picture of the Shici tropes in Sufi poetry at the beginning of the 20th century. The Shici tropes he pointed out can be classified in three parts. He starts with the military vocabulary. Many words are used for introducing Karbala as a war; first of all is jang, but many other Sindhi words are also used.

For example, there is the interesting word piru for Karbala which is explained as jang jo maidān (Beg, 1913: 133). The name of piru was also given to the place where were kept the artefacts to be paraded for Moḥarram, also known as imāmbārā. Beside this, another trope is that of the Prophet's offspring. Beg gives many words related to the Prophet Muhammad's daughter and grandchildren. Fātima is referred to as a protective figure, she is bībì, the princess, or janat khātūn, the Dame of the Paradise. Another topic highlighted by Beg is that of shām. For him, Karbala is shām walāyat. ${ }^{678}$ The word shām means evening, and also Syria, the 'historical' Syria that is today Syria and Lebanon. In Shici context, the mention of the word predicts the terrible suffering that Husayn's little daughter will have to undergo upon reaching Yazīd's capital in that land ${ }^{679}$ But in Sindhi, the word shām is also used in a metaphorical way to express the idea of a place of refuge. It is obviously this last meaning Beg was referring to: Karbala as shām walāyat means that Karbala was the place where both

\footnotetext{
${ }^{678}$ Mīrzā Qalīch Beg, Lughat lațîfi (Hyderabad, 1913), p. 137.

${ }^{679}$ Hyder, Reliving Karbala, p. 27.
} 
Husayn and through him the institution of the imamate took refuge, before to be slaughtered by their enemies.

After partition, a new thread was added to the tapestry of Shicism in Sindh. A number of Muslims who migrated from India in 1947, known as Mohājirs, were Shicis, especially those coming from the northern cities including the Shici centres of Lucknow and Amroha, but also from Hyderabad in Dekkan. There is thus an interesting connection in relation to the encounter between the Sindhi Shicis and the Mohājir Shicis. Mohājir Shicism was an offspring of the courtly Shici culture expressed in Urdu. In Sindh, although the Persian school was centred in the Khairpur courtly culture, Shicism was mainly interwoven with Sufi poetry.

Regarding the encounter between the two Shicisms, a key figure was 'Allāma Rāshid Turābī (1392/1973). According to Hyder, Turābī was probably the best żākir of the Indian subcontinent. ${ }^{680}$ He was born in Hyderabad (Dekkan), and graduated from the Shica College of Lucknow. He migrated to Pakistan in 1949 and was much acclaimed for the thousands of zikrs he delivered in many countries, and was acknowledged by the main shici clerics from Iran and Iraq. Although, he was fond of Mīr Ānīs (1290/1874) and Mīr Taqī Mīr (1224/1810), Turābī was not a specialist of marsiiyas but nevertheless, through his many żikrs, he was acclaimed as a main specialist on the issue of martyrdom. His fame attracted the interest of the rulers of the Khairpur State, who invited him to deliver zikrs. Finally, the last mìr of Khairpur, Mīr George 'Alī Murād Khān Ṭalpūr, married one of 'Allāma Rāshid Turābī's daughters.

A recent publication by a Sindhi scholar, Khādim Ḥusayn Sūmro, still gives the Sur Kedāro as the source of Sindhi marsiiyas. More than half of the book is devoted to the Sindhi

\footnotetext{
${ }^{680}$ See for example Hyder's detailed analysis of Turābī’s żikr: Hyder, Reliving Karbala, pp. 40-42. He also claims that Turābī's fame was so powerful that he was represented as a member of the ahl al-bayt.
} 
text of Shāh jo risalo with an Urdu translation. ${ }^{681}$ The second part proposes almost 70 authors of Sindhi marsiyas, with a very short biographical notice and the quotation of a few verses. Of course, Sūmro gives excerpts from Śabit, Sachal, Bedil or Beg. Although they are the most popular poets of Sindh, Sūmro treats them like the less known marsiya authors.

His main wish obviously is to give access to Sindhi marsiyas to the Urdu-speaking inhabitants of Sindh. In the second part, Sūmro introduces the marsiyas' authors, and gives an Urdu translation of excerpts of their works. The book can be seen as an attempt to bridge Shicism expressed in Sindhi and Shicism expressed in Urdu from northern India and Dekkan. Nonetheless, the Mohājirs still sing Mīr Ānīs's marsiyyas in Urdu, in Karachi, Hyderabad, and in all other cities of Sindh where they settled after partition.

\section{Conclusion}

The marsiya appears simultaneously in the literature of Sindh both in Persian and in Sindhi. There is evidence of the role played by Kāshifī's Rawdat al-shuhadā'. It was translated into Sindhi in the 18th century and one can find Sindhi versions in different collections. In Shāh 'Abd al-Lațîf's Shāh jo risālo, the chapter Sur Kedāaro definitively incorporated the motif of Ḥusayn's martyrdom in Sufi poetry. This is obviously a watershed in Sindhi Sufi poetry and also in Sindhi literature. Furthermore, in giving a detailed description in Sindhi, Shāh 'Abd al-Latîf claims that martyrdom, or sacrifice in general, paved the way for union with God, known as fana $\bar{a}^{\prime}$ fìllāh in Sufi parlance. One can say that martyrdom thus became a trope. But beyond the issue of literature, two events can also explain the spread of the marsiya.

First is the decline of the Mughal empire after Aurangzeb's death. The following invasions largely contributed to the spread of insecurity into Sindh. Second, in the late 18th

\footnotetext{
${ }^{681}$ Khādim Ḥusayn Sūmro, Sur Kedāāro awr Sindhī marsiiya kī mukhtaṣar ājmālì tārīkh (Sehwan Sharif, 2000), p. 15-110.
} 
century, a Baluch clan, the Țalpūrs, who were Twelver Shicis, seized power and ruled Sindh. As soon as they seized power, they started to patronise Shici poets and Shici ceremonies. A number of the Talpūr dynasty members were themselves poets and the main specialist of marsiyas in Sindhi flourished thanks to the liberality of the Ṭalpūr rulers of Hyderabad. Sābit 'Alī Shāh rouse to fame and still today, his marsiiyas form the bulk of the mourning songs performed for Moharram. After the British conquest of 1258/1843, the Princely State of Khairpur became the last territory of Sindh where the Shici poets were patronised.

In this context, the word marsiya was used for any work of literature devoted to the martyrdom of Imam Husayn and his family at Karbala. Sometimes, the vernacular Sindhi word vāvillā was also used. In the wake of Shāh 'Ināyat's martyrdom, one can probably observe a shift where the figure of martyrdom is a Sufi, but whose martyrdom is framed on the pattern of Imam Husayn at Karbala. It started with Dalpat Sufi's Jang Nāma centred on Shāh 'Ināyat, and it was more fully articulated with Sachal Sarmast focusing on Manșūr alḤallāj's martyrdom.

In the early 20th century, there was an attempt to build a Shici qawm in Sindh through the publication of marsiyas and nohās, and the involvement of the leading Shica of Sindh in a wider process spreading all over colonial India. Later, despite the coming of North-Indian Shicia after 1947, who were Urdu speaking, the main characteristic of Sindhi marsiya is still its embodiment of Sufi poetry, although one cannot deny the parallel development of a distinct tradition, enhanced by some powerful Shici families from interior Sindh. The latter is today only expressed in Sindhi since the use of Persian has totally vanished. 